\title{
Quantitative Evaluation of the Extent of Hepatic Enzyme Changes in Reye Syndrome Compared with Normal Liver or with Non-Reye Liver Disorders: Objective Criteria for Animal Models
}

\author{
R. A. MITCHELL, E. L. ARCINUE, J. C. PARTIN, J. S. PARTIN, M. L. RAM, C. H. CHANG, \\ J. SMIALEK, AND A. SARNAIK \\ Departments of Biochemistry, Pediatrics and Pathology, Wayne State University, the Children's Hospital of \\ Michigan, Detroit, Michigan, the Children's Hospital of Los Angeles, California; and the Children's Hospital \\ Research Foundation, Cincinnati, Ohio
}

\begin{abstract}
Five enzymes were measured in 50 liver specimens (18 normal liver, 20 Reye liver, 12 diverse liver disorders other than Reye syndrome). The enzymes were: glutamic dehydrogenase (E.C. 1.4.1.3), monoamine oxidase (E.C. 1.4.3.4), lactate dehydrogenase (E.C. 1.1.1.27), Dglucose-6-phosphate dehydrogenase (E.C. 1.1.1.49), catalase (E.C. 1.11.1.6). The Reye syndrome group showed significant decreases in glutamic dehydrogenase $(56 \%)$ and monoamine oxidase $(\mathbf{7 0} \%$ ) compared to normal control tissue and these changes were not characteristic of the nonReye liver disorder group as a whole. Neither catalase nor lactate dehydrogenase appeared to be altered significantly in the Reye or in the abnormal control group compared with normal controls. Thus, only the prominent decreases in the mitochondrial enzyme activities appeared to be highly characteristic of Reye syndrome. Paradoxically, the means of the five hepatic enzymes and the admission levels of two serum enzymes indicative of liver damage (alanine and aspartate aminotransferase ) were remarkably similar for both survivors and nonsurvivors of Reye syndrome. (Pediatr Res 19: 19-22, 1985)
\end{abstract}

\section{Abbreviations}

AlaT, alanine aminotransferase

Asp'T, aspartate aminotransferase

CATAL, catalase

GDH, glutamic dehydrogenase

GPDH, glucose 6-phosphate dehydrogenase

LDH, lactate dehydrogenase

MAO, monoamine oxidase

Twenty years ago Reye et al. (11) in Sydney, Australia, described an encephalography with hepatic involvement as a new and distinct disease entity of childhood. The salient clinical and pathologic features of Reye syndrome have been reviewed previously $(1,2,4-6,14)$. The hepatic changes have been described in detail at the gross and microscopic levels. Panlobular light and ultramicroscopic changes occur uniformly throughout the liver,

Received March 15, 1984; accepted July 11, 1984.

Correspondence to Dr. R. A. Mitchell, Biochemistry Department, 540 E. Canfield, Wayne State University School of Medicine, Detroit, MI 48201.

This work was supported by the Reye Syndrome Study Center, Children's Hospital of Michigan. without signs of necrosis or biliary stasis. Light and electron microscopic analysis of hepatocytes show an accumulation of microvesicular fat droplets, proliferation of smooth endoplasmic reticulum, glycogen depletion, loss of very low-density lipoprotein particles from the Golgi apparatus, an increase in the number of peroxisomes, and extensive mitochondrial ultrastructural changes. These include mitochondrial swelling with rarification of the matrix, pleomorphism with the appearance of amoeboidlike forms, loss of dense-staining bodies, and reduced succinate dehydrogenase activity as measured by histochemical staining (2). The mitochondrially located urea cycle enzymes (ornithine transcarbamylase and carbamyl phosphate synthetase) also were found to be decreased in activity, prompting suggestions that this deficit could contribute to hyperammonemia $(3,9,15,17)$. To date no comparable evidence for a generalized mitochondrial enzyme deficit has been found in brain or skeletal muscle $(12$, 13). Either the mitochondrial lesion is unique to the liver, or mitochondrial lesions in other tissues may be focal rather than uniformly distributed throughout the tissue.

The above considerations suggest that a better understanding of the hepatic changes in Reye syndrome, particularly the biochemical alterations, might provide better insights into the origin of the illness and its subsequent progression. Therefore we elected to delineate the biochemical changes in liver with a view to providing a quantitative description of the key features of the disease. Such information should provide objective criteria for evaluating animal models of Reye syndrome.

\section{METHODS}

Patient population. Liver specimens were obtained from patients admitted to the Children's Hospital of Michigan, Detroit, MI or to the Children's Hospital, Cincinnati, OH, between 1977 and 1981. Specimens obtained either by needle biopsy or at time of autopsy were obtained with the parents' consent. Liver specimens for the normal infant group were submitted for study by the Office of the Wayne County Medical Examiner. Values for AlaT and AspT were obtained from blood samples taken at the time of admission. For purposes of statistical analysis the cases were assigned to one of three groups (normal liver, Reye syndrome, other types of liver pathology), based on case history, clinical diagnosis, liver pathology, etc.

Assay of enzyme activities in liver tissue. Four enzymes were time assayed by the congruent assay procedure described previously (10). A fifth enzyme, CATAL, was assayed by measuring the first order rate constant for the disappearance of hydrogen 
peroxide as followed by decrease in absorption at $240 \mathrm{~nm}$. The five enzymes (LDH, GDH, MAO, CATAL, GPDH) were assayed using an Aminco DW-2 spectrophotometer and specific activity was expressed as units of enzyme activity per milligram of soluble or particulate protein, as appropriate, depending on the location of activity following high-speed centrifugation of the tissue homogenate.

Statistical analysis of data. Enzyme activities measured as above were obtained from 50 human liver specimens. The reproducibility of the assays was tested during the study, using tissue from two normal and two Reye cases, as described in "Results". The significance of differences between means was determined by one-way analysis of variance or by Student's $t$ test using either a pooled or separate variance estimate based on the F statistic.

\section{RESULTS}

Patient and control admission data. Table 1 summarizes available admission data for 33 cases. No blood chemistry data were available for many of the normal liver control cases where liver tissue was obtained at autopsy within $12 \mathrm{~h}$ of unexpected death.

Table 1. Available admission data for control cases (no liver disorder, group 1), Reye syndrome (group 2), and liver disorders other than Reye syndrome (Group 3)

\begin{tabular}{|c|c|c|c|c|c|c|}
\hline ID & Diagnosis & Group & Sex & $\begin{array}{l}\text { Age } \\
(\mathrm{yr})\end{array}$ & $\begin{array}{c}\text { AspT } \\
\text { (IU/li- } \\
\text { ter) }\end{array}$ & $\underset{\text { (IU/liter) }}{\text { AlaT }}$ \\
\hline $\mathrm{R} 705$ & Reye & 2 & $\mathrm{~F}$ & 3.9 & 258 & 309 \\
\hline $\mathrm{R} 802$ & Reye & 2 & $\mathbf{M}$ & 4.6 & 1310 & 1755 \\
\hline $\mathrm{R} 810$ & Reye & 2 & $\mathrm{~F}$ & 7.6 & 960 & 1050 \\
\hline $\mathrm{R} 811$ & Reye & 2 & F & 7.2 & 610 & 1320 \\
\hline R902 & Reye & 2 & M & 9.0 & 370 & 760 \\
\hline R907 & Reye & 2 & M & 12.2 & 104 & 231 \\
\hline 3 & Recovered Reye & 1 & $\mathrm{~F}$ & 6.4 & 42 & 32 \\
\hline 4 & Varicella & 3 & M & 13.0 & 46 & 52 \\
\hline 5 & $\begin{array}{l}\text { Gastroenteritis, with } \\
\text { fatty liver }\end{array}$ & 3 & $\mathrm{~F}$ & 6.7 & 322 & 230 \\
\hline 6 & $\begin{array}{l}\text { Diarrhea, ear infec- } \\
\text { tion }\end{array}$ & 3 & $\mathrm{~F}$ & 1.9 & 742 & 746 \\
\hline 7 & $\begin{array}{l}\text { Unknown metabolic } \\
\text { disorder }\end{array}$ & 3 & $\mathbf{M}$ & 8.1 & 60 & 136 \\
\hline 8 & $\begin{array}{l}\text { Hepatitis (mononu- } \\
\text { cleosis) }\end{array}$ & 3 & $\mathrm{~F}$ & 9.0 & 722 & 784 \\
\hline 9 & Reye & 2 & $\mathrm{~F}$ & 11.6 & 352 & 528 \\
\hline 10 & Reye & 2 & $\mathrm{~F}$ & 2.1 & 306 & 406 \\
\hline 13 & Reye & 2 & $\mathbf{M}$ & 14.3 & 1820 & 2420 \\
\hline 14 & Reye & 2 & $\mathbf{M}$ & 5.3 & 866 & 1680 \\
\hline 15 & Reye & 2 & $\mathrm{~F}$ & 3.2 & 882 & 740 \\
\hline 16 & Reye & 2 & $\mathrm{M}$ & 1.9 & 92 & 52 \\
\hline 17 & $\begin{array}{l}\text { Hepatitis (Epstein- } \\
\text { Barr virus) }\end{array}$ & 3 & $\mathrm{M}$ & 13.8 & 512 & 686 \\
\hline 18 & $\begin{array}{l}\text { Acetaminophen ov- } \\
\text { erdose }\end{array}$ & 3 & $\mathrm{~F}$ & 17.0 & 242 & 344 \\
\hline 19 & Encephalitis & 1 & $\mathrm{~F}$ & 10.3 & 30 & 19 \\
\hline 20 & Reye & 2 & $M$ & 21.4 & 350 & 790 \\
\hline 24 & Reye & 2 & $\mathrm{M}$ & 6.3 & 259 & 700 \\
\hline 25 & Reye & 2 & M & 11.5 & 660 & 530 \\
\hline 26 & Reye & 2 & $\mathrm{~F}$ & 10.6 & 217 & 38 \\
\hline 27 & Reye & 2 & $\mathrm{~F}$ & 6.9 & 1400 & 640 \\
\hline 28 & Reye & 2 & $M$ & 15.4 & 340 & 307 \\
\hline 29 & Hepatitis & 3 & $\mathrm{~F}$ & 3.0 & 820 & \\
\hline 30 & Reye & 2 & $\mathbf{M}$ & 5.2 & 363 & 83 \\
\hline 34 & Unknown & 3 & M & 3.6 & 302 & \\
\hline 36 & $\begin{array}{l}\text { Urea cycle defi- } \\
\text { ciency }\end{array}$ & 3 & M & 0.8 & 35 & 41 \\
\hline 39 & Reye & 2 & M & 8.0 & 240 & \\
\hline 41 & $\begin{array}{l}\text { Methylmalonic aci- } \\
\text { duria }\end{array}$ & 3 & $\mathrm{~F}$ & 0.5 & & \\
\hline
\end{tabular}

This control sample contained cases of cardiopulmonary arrest, cerebral hemorrhage, asphyxiation, smoke inhalation, multiple injuries, and sudden infant death syndrome.

Are the enzyme analyses reproducible? Potential sources of error in the analysis of enzyme activities in liver tissue include time-dependent changes during tissue storage in liquid nitrogen, variations in sampling due to nonuniform distribution of activity within the specimen of liver tissue, and errors in measurements of enzyme activity and protein concentration. To assess the overall reproducibility of the assays over the time period of the study ( $2 \mathrm{yr})$, the five enzymes were routinely assayed in stored tissue using tissue aliquots from two Reye and two normal liver control specimens. None of the enzymes showed evidence for time-dependent changes over the 2-yr test period, either for the Reye or the control group (Table 2).

Are there significant differences in liver enzyme activities between three predefined groups (normal, Reye, and liver disorders other than Reye)? The five criterion enzymes were measured in 50 liver specimens (18 normal, 20 Reye, and 12 diverse liver disorders other than Reye syndrome). Results are shown in Table 3. For LDH the grand mean of all three groups was 769 units and there were no significant differences between any pair of groups.

For GDH the mean of the Reye group was considerably lower than both the normal and the abnormal control groups and these difference were significant $(p<0.05)$. Nevertheless, the greatest difference was the decrease in Reye group activity compared with normal. With MAO, significant $(p<0.05)$ and striking differences were found when the Reye group was compared with either the normal or the abnormal control groups. By contrast, the small difference between the normal and abnormal control groups was not significant. With CATAL all groups were close to the grand mean, (360 units) and there were no statistically

Table 2. Reproducibility of enzyme assay procedures*

\begin{tabular}{|c|c|c|c|c|c|}
\hline Case & $n$ & Mean & SD & $\mathrm{SE}$ & $p$ \\
\hline \multicolumn{6}{|l|}{$\mathrm{LDH}$} \\
\hline $\mathrm{Cl}$ & 8 & 775 & 79 & 28 & \multirow{2}{*}{0.027} \\
\hline $\mathrm{C} 2$ & 8 & 909 & 128 & 45 & \\
\hline $\mathrm{R} 811$ & 7 & 709 & 101 & 38 & \multirow{2}{*}{$<0.001$} \\
\hline R902 & 7 & 984 & 92 & 38 & \\
\hline \multicolumn{6}{|l|}{ GDH } \\
\hline $\mathrm{Cl}$ & 8 & 113 & 21 & 7 & \multirow{2}{*}{0.001} \\
\hline $\mathrm{C} 2$ & 8 & 156 & 20 & 7 & \\
\hline R811 & 7 & 55 & 29 & 11 & \multirow{2}{*}{ NS } \\
\hline R902 & 7 & 46 & 9 & 4 & \\
\hline \multicolumn{6}{|l|}{ MAO } \\
\hline $\mathrm{C} 1$ & 8 & 316 & 62 & 22 & \multirow{2}{*}{0.006} \\
\hline $\mathrm{C} 2$ & 8 & 424 & 70 & 25 & \\
\hline R811 & 7 & 167 & 47 & 18 & \multirow{2}{*}{$<0.001$} \\
\hline R902 & 7 & 50 & 27 & 10 & \\
\hline \multicolumn{6}{|l|}{ CATAL } \\
\hline $\mathrm{Cl}$ & 8 & 505 & 49 & 17 & \multirow{2}{*}{0.004} \\
\hline $\mathrm{C} 2$ & 7 & 422 & 43 & 16 & \\
\hline R811 & 6 & 351 & 51 & 21 & \multirow{2}{*}{0.001} \\
\hline R902 & 7 & 227 & 20 & 8 & \\
\hline \multicolumn{6}{|l|}{ GPDH } \\
\hline $\mathrm{Cl}$ & 8 & 51 & 8 & 3 & \multirow{2}{*}{ NS } \\
\hline $\mathrm{C} 2$ & 8 & 46 & 6 & 2 & \\
\hline R811 & 6 & 65 & 12 & 5 & \multirow{2}{*}{ NS } \\
\hline R902 & 7 & 76 & 14 & 5 & \\
\hline
\end{tabular}

* Specific activities are expressed as: $\mathrm{LDH}, \mathrm{GDH}=($ activityy in IU $\times$ $\left.10^{3}\right)$ per $\mathrm{mg}$ of soluble protein. GPDH $=\left(\right.$ activity in $\left.\mathrm{IU} \times 10^{4}\right)$ per $\mathrm{mg}$ of soluble protein. CATAL $=$ (first order rate constant for hydrogen peroxide loss, in $\mathrm{min}^{-1} \times 10^{2}$ ) per $\mathrm{mg}$ of soluble protein. $\mathrm{MAO}=$ (activity in $\mathrm{IU} \times 10^{5}$ ) per $\mathrm{mg}$ of particulate protein. 
Table 3. Group comparisons of liver enzyme activity for Reye and two control groups*

\begin{tabular}{|c|c|c|c|c|c|}
\hline Group & $n$ & Mean & SD & $\mathrm{SE}$ & $\begin{array}{c}\text { Significant } \\
\text { pairs }\end{array}$ \\
\hline \multicolumn{6}{|l|}{$\mathrm{LDH}$} \\
\hline Normal & 18 & 813 & 232 & 55 & None \\
\hline Reye & 20 & 770 & 273 & 61 & \\
\hline Other & 12 & 703 & 231 & 67 & \\
\hline \multicolumn{6}{|l|}{ GDH } \\
\hline Normal & 18 & 131 & 27 & 6 & a a \\
\hline Reye & 20 & 58 & 21 & 5 & aa \\
\hline Other & 12 & 102 & 37 & 11 & aa \\
\hline \multicolumn{6}{|l|}{ MAO } \\
\hline Normal & 18 & 338 & 84 & 20 & $\mathrm{a}$ \\
\hline Reye & 20 & 105 & 85 & 19 & aa \\
\hline Other & 12 & 313 & 175 & 50 & $\mathrm{a}$ \\
\hline \multicolumn{6}{|l|}{ CATAL } \\
\hline Normal & 18 & 362 & 88 & 21 & None \\
\hline Reye & 20 & 352 & 80 & 18 & \\
\hline Other & 12 & 365 & 119 & 34 & \\
\hline \multicolumn{6}{|l|}{ GPDH } \\
\hline Normal & 18 & 32 & 13 & 3 & $\mathrm{a}$ \\
\hline Reye & 20 & 46 & 18 & 4 & \\
\hline Other & 12 & 67 & 59 & 17 & a \\
\hline
\end{tabular}

*Enzyme activities expressed as described for Table 2. Statistically different means are denoted by vertical pairs of letters.

significant differences between any pairs of groups. With GPDH both the Reye and the abnormal control groups were elevated with respect to the Reye group, although only the 2 -fold elevation of the non-Reye group was significant.

In summary, the Reye syndrome group showed significant decrease in $\mathrm{GDH}(56 \%)$ and $\mathrm{MAO}(70 \%)$ compared to normal control tissue and these changes were not characteristic of the non-Reye liver disorder group as a whole. Neither CATAL nor LDH appeared to be altered significantly in the Reye or in the abnormal control group compared with normal controls. Moreover, although GPDH appeared to be somewhat elevated with respect to normal tissue in both the Reye and the abnormal control group, the elevation was not found to be significant for Reye syndrome in the population tested. Thus, only the prominent decreases in the mitochondrial enzyme activities appeared to be highly characteristic of Reye syndrome.

Are there statistically significant differences in liver enzyme activities between Reye survivors and nonsurvivors? The decreases in GDH and MAO activities found with the Reye syndrome group appeared to represent a highly characteristic feature of the syndrome. The Reye cases in this study encompassed a wide range of severity, spanning stages $\mathrm{I}-\mathrm{V}$ at the time the liver specimen was obtained. However, inspection of the enzyme data showed in general a close similarity in mitochondrial enzyme activities between patients biopsied at stage I, and who survived, and stage $\mathrm{V}$ nonsurvivors.

To evaluate the effect of altered enzyme activities on outcome, Reye cases were assigned to one of two groups, based on survival. Admission levels of AspT and AlaT also were included, since these activities may indirectly reflect liver impairment. The means for the five hepatic and the two serum enzymes did not differ significantly between survivors and nonsurvivors (Table 4).

\section{DISCUSSION}

The results of this study confirm and extend previous reports of selective mitochondrial impairment of liver enzymes. Moreover, a highly reproducible, strictly quantitative assay system was used to measure the activities of a carefully selected group of criterion enzymes in liver specimens from a wide range of cases. The cases included Reye syndrome patients (stages I-V), from infants to adult, who had been admitted to either of two different institutions, and whose diagnosis of Reye syndrome had been confirmed by light and electron microscopic analysis of liver tissue obtained by biopsy or necroscopy. In addition, the study employed two control groups, to permit comparisons of the extent of Reye syndrome changes compared with normal tissue, and to see if changes in mitochondrial enzyme activity are unique to the syndrome. The enzyme activities selected for study included the cytosolic enzymes (LDH, GPDH), the peroxisomal enzyme, CATAL), and two mitochondrial enzymes, GDH and MAO.

Because $\mathrm{LDH}$ is a ubiquitous enzyme catalyzing a readily reversible reaction it is not a likely candidate as a key regulatory enzyme, and may serve as a reference enzyme in Reye syndrome (10). Unlike LDH, GPDH is a branch point enzyme that can direct reducing equivalents derived from glucose away from the respiratory chain and toward the NADPH-producing pentose shunt reactions. No significant increase in GPDH activity was found in Reye syndrome, although such an elevation was found for non-Reye liver disorders.

CATAL was not elevated in the Reye syndrome population compared with the control groups. This finding is of interest, since morphologic studies showed an increase in the number of peroxisomes in Reye syndrome liver, prompting the speculation that peroxisomal activity may have increased at the expense of mitochondrial oxidative activity. While this possibility may yet be correct, the present study provides no evidence for a simple relation between morphologic changes and enzyme activity.

The mitochondrial enzymes activities were found to be decreased consistently and markedly in Reye syndrome but not in cases of other liver disorders. The extent of this decrease is comparable to that reported (16) for the mitochondrial enzyme ornithine transcarbamylase, although the decrease in GDH

Table 4. Comparisons of liver and serum enzyme activities for survivors and nonsurvivors of Reye syndrome*

\begin{tabular}{|c|c|c|c|c|c|}
\hline Group & $n$ & Mean & $\mathrm{SD}$ & $\mathrm{SE}$ & $\begin{array}{c}\text { Significant } \\
\text { at } \\
\mathrm{p}<0.05 ?\end{array}$ \\
\hline \multicolumn{6}{|l|}{ LDH } \\
\hline Nonsurvivor & 12 & 855 & 306 & 88 & No \\
\hline Survivor & 8 & 641 & 154 & 54 & \\
\hline \multicolumn{6}{|l|}{ GDH } \\
\hline Nonsurvivor & 12 & 59 & 20 & 6 & No \\
\hline Survivor & 8 & 56 & 23 & 8 & \\
\hline \multicolumn{6}{|l|}{ MAO } \\
\hline Nonsurvivor & 12 & 100 & 70 & 20 & No \\
\hline Survivor & 8 & 111 & 108 & 38 & \\
\hline \multicolumn{6}{|l|}{ CATAL } \\
\hline Nonsurvivor & 12 & 331 & 90 & 26 & No \\
\hline Survivor & 8 & 384 & 51 & 18 & \\
\hline \multicolumn{6}{|l|}{ GPDH } \\
\hline Nonsurvivor & 12 & 45 & 19 & 6 & No \\
\hline Survivor & 8 & 46 & 16 & 6 & \\
\hline \multicolumn{6}{|l|}{ AspT } \\
\hline Nonsurvivor & 12 & 534 & 363 & 105 & No \\
\hline Survivor & 8 & 670 & 627 & 222 & \\
\hline \multicolumn{6}{|l|}{ AlaT } \\
\hline Nonsurvivor & 11 & 803 & 596 & 180 & No \\
\hline Survivor & 8 & 702 & 751 & 265 & \\
\hline
\end{tabular}

\footnotetext{
* Enzyme activities expressed as described for Table 2.
} 
found here was less than that reported by Robinson et al. (13), who found a $90 \%$ decrease of activity, based on a wet weight comparison. The reason for this discrepancy is unknown; an approximate estimate of the enzyme content of our specimens on a wet weight basis indicated that the normal control values for GDH as well as previously reported (10) values for glucose 6-phosphatase in Reye and control cases were quite similar to those reported by Robinson et al. (13).

The decreased levels of activity may reflect a decreased level of mitochondrial protein. Although attempts were made to distinguish between Reye and control cases by analyzing the readily solubilized protein fraction from Reye and normal liver using a 2-dimensional gel electrophoresis, no consistent pattern of mitochondrial protein depletion could be found because of the complexity of the resulting electrophoretogram (R. A. Mitchell, unpublished results). Decreased activity could result either from impaired mitochondrial biogenesis or from an increased rate of mitochondrial protein turnover. Because mitochondria exist as semiautonomous organelles subject to non-Mendelian genetic defects (7), for example, it is possible that an unknown agent causes an early, transient decrease in the mitochondrial hepatocyte activity, either by impairing mitochondrial biogenesis, or by increasing mitochondrial degradation. It is of interest that only two non-Reye cases (Epstein-Barr virus and giant cell hepatitis) showed mitochondrial enzyme decreases similar to those of Reye cases. Detection of other cases of mitochondrial impairment $(e . g$. by histochemical staining for succinate dehydrogenase activity) may provide useful insights into Reye etiology. An association between Epstein-Barr virus infection and Reye syndrome has been reported (8).

The present study confirms the view that mitochondrial changes in hepatic tissue are highly characteristic of Reye syndrome, although as noted above, not unique to it. It must be emphasized that these findings apply only to liver and cannot be extrapolated to brain or skeletal muscle, where biochemical analysis indicates no decrease in mitochondrial enzyme activity (13). Indeed, abnormally high catabolic activity in muscle, leading to excessive production of ammonia (16), suggests an increased rather than a decreased oxidative metabolism in muscle.

Quantitative analysis of the selected mitochondrial enzymes also confirms the seeming paradox that the severity of the liver damage (as judged by elevation of serum transaminase) is poorly related to outcome. This conclusion is clear from the comparison of enzyme activities between Reye survivors and nonsurvivors. Additional factors appear to be involved in determining the extent of neurologic damage.
In summary, decreased hepatic activity of GDH (56\%) and MAO (70\%) was highly characteristic of Reye syndrome but not unique to it. Nevertheless, the levels of these mitochondrial enzymes were not significantly different between survivors and nonsurvivors, thereby pointing to additional factors responsible for the severity of the encephalopathy. This suggests that animal models for Reye syndrome should at least show an similar depletion of these activities, possibly associated with highly variable degrees of encephalopathy.

\section{REFERENCES}

1. Alvira MA, Forman DT 1974 Biochemical abnormalities in Reye's Syndrome. Ann Clin Lab Sci 4:477-483

2. Bove KE, McAdams AJ, Partin JC, Partin JS, Hug G, Schubert WK 1975 Hepatic lesion in Reye's syndrome. Gastroenterology 69:685-697

3. Brown T, Hug G, Lansky L, Bove K, Scheve A, Ryan M, Brown H, Schubert WK, Partin JC, Lloyd-Still J 1976 Transiently reduced activity of carbamyl phospahate synthetase and ornithine transcarbamylase in liver of children with Reye's syndrome. N Engl J Med 294:861-867

4. Crocker JFS, Bagnell PC 1981 Reye's syndrome: a clinical review. Can Med Assoc J 124:375-425

5. DeLong GR, Glick TH 1982 Encephalopathy of Reye's syndrome: a review of pathogenetic hypothesis. Pediatrics 69:53-63

6. DeVivo DC, Keating JP 1976 Reye's syndrome. Adv Pediatr 22:175-229

7. Egger J, Wilson J 1983 Mitochondrial inheritance in a mitochondrially mediated disease. N Engl J Med 309:142-146

8. Fleisher G, Schwartz J, Lennette E 1980 Primary Epstein-Barr virus infection in association with Reye syndrome. J Pediatr 97:935-937

9. Kang ES, Gerald PS 1972 Hyperammonemia and Reye's syndrome. N Engl J Med 286:1216-1217

10. Mitchell RA, Ram ML, Arcinue EL, Chang CH 1980 Comparison of cytosolic and mitochondrial hepatic enzyme alterations in Reye's syndrome. Pediatr Res 14:1216-1221

11. Reye RKD, Morgan G, Baral J 1963 Encephalopathy and fatty degeneration of the viscera: a disease entity in childhood. Lancet 2:749-752

12. Robinson BH, Gall DG, Cutz E 1977 Deficient activity of hepatic pyruvate dehydrogenase and pyruvate carboxylase in Reye's syndrome. Pediatr Res 11:279-281

13. Robinson, BH, Taylor J, Cutz E, Gall DG 1978 Reye's syndrome: preservation of mitochondrial enzymes in brain and muscle compared with liver. Pediatr Res 12:1045-1047

14. Schubert WK, Partin JC, Partin JS 1972 Encephalopathy and fatty liver (Reye's syndrome). In: Popper H, Schaffner F (eds), Progress in Liver Disease. pp 489-510

15. Sinatra F, Yoshida T, Applebaum M, Mason W, Hoogenraad NJ, Sunshine $P$ 1975 Abnormalities of carbamyl phosphate synthetase and ornithine transcarbamylase in liver of patients with Reye's syndrome. Pediatr Res 9:829833

16. Snodgrass PJ, DeLong GR 1976 Urea-cycle enzyme deficiencies and an increased nitrogen load producing hyperammonemia in Reye's syndrome. N Engl J Med 294:855-860

17. Thaler MM, Hoogenraad NJ Boswell M 1974 Reye's syndrome due to a novel protein-tolerant variant of ornithine transcarbamylase deficiency. Lancet 2:438-440 